\title{
621 Al 合金(JIS A7N01)のフレッティング疲労強度に及ぼす固体潤滑被膜の影響 \\ Effect of bonded solid lubricant on fretting fatigue strength of aluminum alloy (JIS A7N01)
}

\section{○正 西田友久 （沼津高専） 正 水谷淳之介 （富山商船高専） 正 武藤睦治 （長岡技科大） 学 勝俣悠樹 （沼津高専専攻科） 正 川邑正広 (怢川邑研究所） 今岡 亮 （ヤマハ発動機秼）}

Tomohisa NISHIDA, Numazu College of Tech. 3600 Ooka, Numazu,410-8501

Junnosuke MIZUTANI, Toyama College of Maritime Tech. 1-2 Ebie Neriya, Imizu, 933-0293

Yoshiharu MUTOH, Nagaoka Univ., of Tech. 1603-1 kamitomioka, Nagaoka, 940-2188

Yuki KATSUMATA, Numazu College of Tech. 3600 Ooka, Numazu, 410-8501

Masahiro KAWAMURA, Kawamura Research Lab. 5-6, Meguro, Meguro-ku, Tokyo, 153-0063

Ryou IMAOKA, Yamaha Motor Co.,Ltd. 2500 Shingai, Iwta, 438-8501

Key Words : Fretting Fatigue, Fatigue, Bonded Solid Lubricant, Tangential Force.

\section{1. 緒言}

近年、省資源や地球環境の観点から機械構造物の軽量化、 生産性の向上、低コスト化が要求され、アルミニウム合金の 使用が拡大している。一方、構造部材としては通常疲労のみ ならずフレッティング疲労が重要な問題であることが知られ ている1）2)。アルミニウム合金 JIS A7N01 は高強度で溶接性 に優れているためオートバイなどの構造部材として広く採用 されているが、そのフレッティング疲労強度特性や防止策に ついては検討されていないのが現状である。

そこで本研究においては、JSA7N01 材のフレッティング 疲労防止策として固体被膜潤滑剂を接触片にコーティングし てフレッティング疲労試験を行い、フレッティング疲労強度 に及ぼす固体潤滑被膜の影響について検討した。

\section{2. 実験方法}

供試材として試験片には展伸用アルミニウム合金（JIS A7N01 材）を、フレッティング疲労試験での接触片には自動 車構造用熱間圧延鋼板（SAPH440 鋼）を用いた。それらの 化学成分および機械的性質をそれぞれ表 1 および 2 に示す。

固体被膜潤滑剤（ポリアミドイミド樹脂、二硫化モリブデ ン、グラファイトと三酸化アンチモンを混合）は、接触片が 試験片と接触する部分を脱脂、サンドブラスト、リン酸処理 の後に噴霧状にして吹き付け、その後 $200^{\circ} \mathrm{C}$ で焼き付けを施 した（以後、固体潤滑材と呼ぶ）。

フレッティング疲労試験片および接触片の形状・寸法を図 1 に示す。フレッティング疲労試験は容量 $100 \mathrm{kN}$ の電気油

Table 1 Chemical composition of JIS 7N01 (mass\%)

\begin{tabular}{c|c|c|c|c|c|c|c|c}
\hline \hline $\mathrm{Si}$ & $\mathrm{Fe}$ & $\mathrm{Cu}$ & $\mathrm{Mn}$ & $\mathrm{Mg}$ & $\mathrm{Cr}$ & $\mathrm{Zn}$ & $\mathrm{Ti}$ & $\mathrm{Zr}$ \\
\hline 0.11 & 0.25 & 0.04 & 0.38 & 1.6 & 0.03 & 4.6 & 0.03 & 0.13 \\
\hline
\end{tabular}

Table 2. Mechanical prorerties of JIS 7N01

\begin{tabular}{c|c|c|c}
\hline \hline $\begin{array}{c}\text { Tensile strength } \\
\sigma_{\mathrm{B}}(\mathrm{MPa})\end{array}$ & $\begin{array}{c}\text { Young's modulus } \\
\mathrm{E}(\mathrm{GPa})\end{array}$ & $\begin{array}{c}\text { Elongation } \\
(\%)\end{array}$ & $\begin{array}{c}\text { Hardness } \\
\mathrm{Hv}(\mathrm{GPa})\end{array}$ \\
\hline 428 & 74 & 14.5 & 1.25 \\
\hline
\end{tabular}

圧式サーボ疲労試験機を用い、完全両振り $(\mathrm{R}=-1)$ の正弦波を 用い、繰返し周波数は $10 \sim 20 \mathrm{~Hz}$ で行った。フレッティング は接触片一対をプルービングリングにより疲労試験片板状部 に押しつけて起こさせ、接触面圧 $50 \mathrm{MPa}$ および $100 \mathrm{MPa}$ 定となるように調節した。また、接線力は接触片裏側に貼付 したひずみゲージにより測定した。なお、フレッティング疲 労試験は日本機械学会基準 JSME S 015 に準じている。

\section{3. 実験結果および考察}

\section{1 フレッティング疲労強度}

未処理材および固体潤滑材のフレッティング疲労試験結果 より得られた $S-N$ 曲線を図 2 に示す。未処理材のフレッテ イング疲労強度はその通常疲労強度に比べて 5 分の 1 程度に 低下し、本供試材は他のアルミニウム合金 $\left.{ }^{2)} 3\right)$ に比べてフレ ッティング疲労の影響を受けやすいことがわかる。なお、同 図には参考としてウェットブラスト処理を施した場合のフレ ッティング疲労試験結果も示しており、固体潤滑材のフレッ ティング疲労寿命は、未処理材やウエットブラスト処理を施 した試験片に比べて著しく向上し、通常疲労強度に近い值と なった。また、同図には固体潤滑材の接触面圧を $100 \mathrm{MPa} に$ 増大した場合のフレッティング疲労寿命も記載してあり、そ

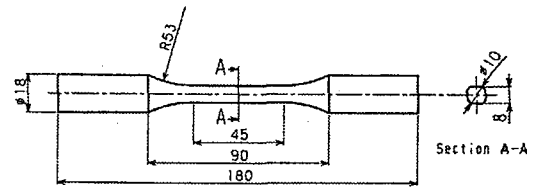

(a) Fretting fatigue specimen

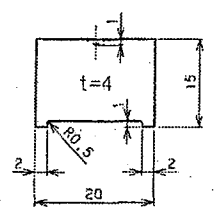

(b) Contact pad

Fig.1 Fretting fatigue specimen and contact pad. 
の疲労寿命は固体潤滑材の接触面圧 $50 \mathrm{MPa}$ に比べるとわず かに低下するものの未処理材に比べて著しく向上し、固体被 膜潤滑剤は接触面圧が増加した場合も有効であることが明ら かとなった。

図 3 に接線力係数と相対すべり振幅の関係を示す。測定数 が少なく正確さに欠けるが、固体潤滑材の接線力係数はいず れの場合も未処理材のそれに比べて著しく低下した。固体潤 滑材のフレッティング疲労寿命が未処理材のそれに比べて向 上したのは固体潤滑被膜の存在により接線力係数が低下し、 フレッティング疲労き裂の発生・進展を遅らせたものと推察 される。

\section{1 電子顕微鏡による表面観察}

フレッティング表面の SEM 観察結果を図 4 に示す。図よ り、未処理材のフレッティング表面は損傷が激しかったのに 対し、固体潤滑材のそれはほとんど損傷が認められなかった。

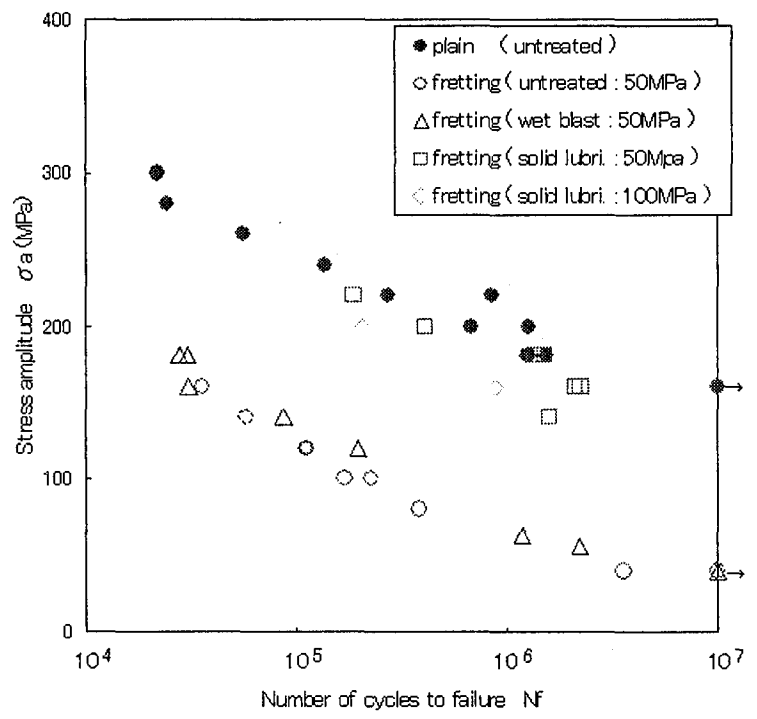

Fig.2 S-N curve ( fretting fatigue).

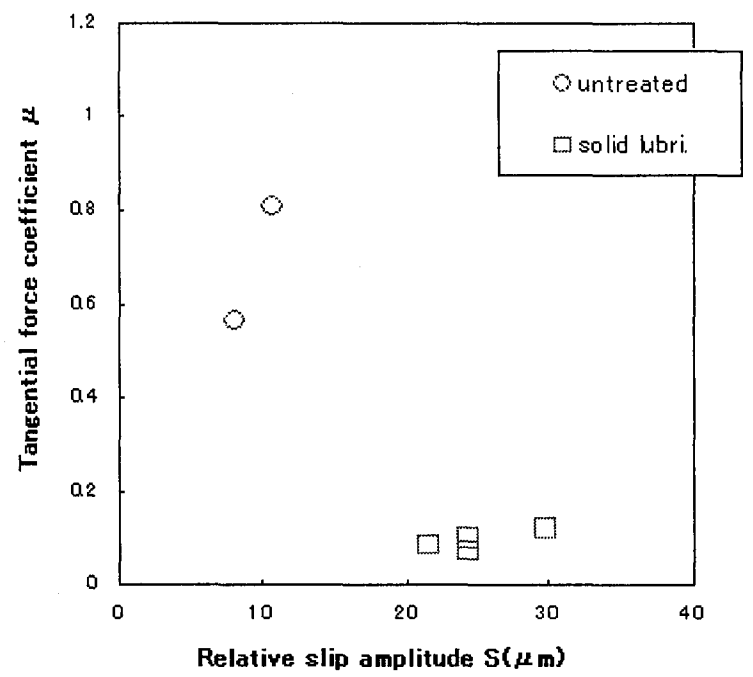

Fig.3 Relationship between tangential force coefficient and relative slip amplitude.
また、図 5 にフレッティング疲労試験前後の接触片表面の SEM 観察結果を示す。試験前は二硫化モリブデン等の粒径が 明確に観察されていたが、試験後はフレッティングの影響に より粒状のものが押しつぶされるあるいは摩耗分として排出 されるが、その後も表面に被膜は存在し続けるため、低い接 線力係数になったものと考えられる。

謝辞 本研究の遂行にあたり、表面処理関連で多大なご協力 を戴いた長泉パーカライジング（株）大貫社長および（株） 不二精機製作所牧野部長に感謝の意を表す。

\section{（結言·参考文献省略）}

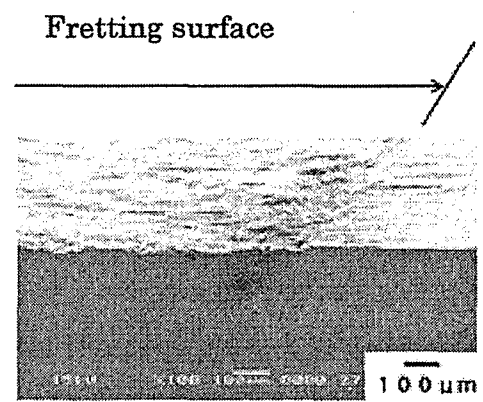

(a) untreated

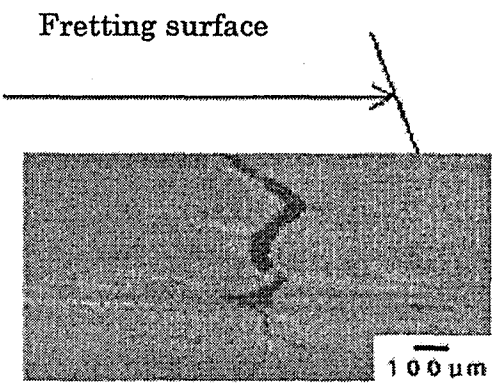

(b) solid lubricant

Fig. 4 SEM observations of specimen surface under fretting fatigue $(\sigma a=160 \mathrm{MPa})$

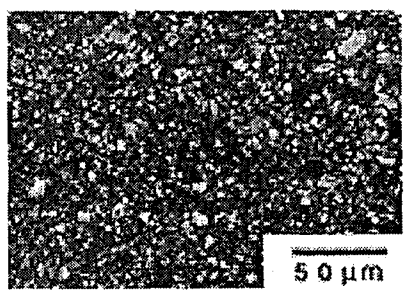

(a) before fretting fatigue test

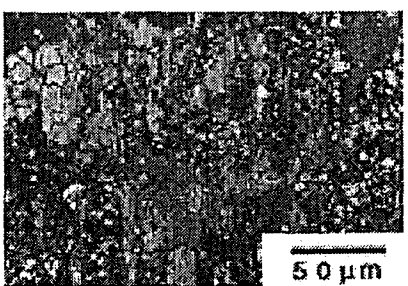

(b) after fretting fatigue test

$(\sigma a=220 \mathrm{MPa})$

Fig.5 SEM observations of contact surface. 